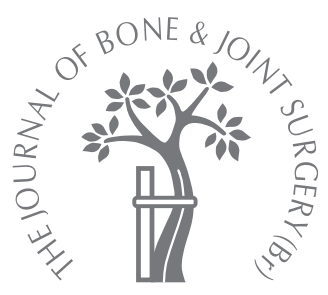

I. Uçkay,

D. Pittet,

L. Bernard,

D. Lew,

A. Perrier,

R. Peter

From University of

Geneva Hospitals

and Faculty of

Medicine, Geneva,

Switzerland

I. Uçkay, MD, Infectious

Disease Consultant

D. Pittet, MD, MS, Professor

of Medicine, Control, Infection

Control Programme

D. Lew, MD, Professor of

Infectious Diseases

A. Perrier, MD, Professor of

Medicine

R. Peter, MD, Professor of

Orthopaedic Surgery

University of Geneva Hospitals

and Faculty of Medicine, 24 Rue

Micheli-du-Crest, 1211 Geneva

14, Switzerland.

- L. Bernard, MD, Professor of Infectious Diseases

Raymond Poincaré University

Hospital, 104 Boulevard

Raymond Poincaré, 92380

Garches, France.

Correspondence should be sent to Professor D. Pittet; e-mail: didier.pittet@hcuge.ch

(C)2008 British Editorial Society of Bone and Joint Surgery doi:10.1302/0301-620X.90B7. $20359 \$ 2.00$

$J$ Bone Joint Surg $[\mathrm{Br}]$ 2008;90-B:833-8.

\title{
Antibiotic prophylaxis before invasive dental procedures in patients with arthroplasties of the hip and knee
}

\author{
More than a million hip replacements are carried out each year worldwide, and the number \\ of other artificial joints inserted is also rising, so that infections associated with \\ arthroplasties have become more common. However, there is a paucity of literature on \\ infections due to haematogenous seeding following dental procedures. We reviewed the \\ published literature to establish the current knowledge on this problem and to determine \\ the evidence for routine antibiotic prophylaxis prior to a dental procedure. \\ We found that antimicrobial prophylaxis before dental interventions in patients with \\ artificial joints lacks evidence-based information and thus cannot be universally \\ recommended.
}

Joint prostheses are one of the remarkable advances of modern medicine. In 1936, the first joint replacement, a total hip replacement, was performed. ${ }^{1}$ Over 70 years later, more than a million hip replacements are carried out annually worldwide. Apart from loosening of the components or dislocation, infection is the most common complication. Although the overall risk has been reduced to $<1 \%$ for hip and $<2 \%$ for knee replacements, ${ }^{2}$ infection is observed quite often owing to the sheer volume of patients who undergo joint replacement. ${ }^{3}$ In the United States, at least 400000 total hip and knee replacements are carried out each year, ${ }^{3-5}$ and approximately 70000 in the United Kingdom. ${ }^{6}$ However, in managing infection of the prosthesis, the costs of treatment are five to seven times higher than the initial operation and the morbidity is considerable. ${ }^{7}$

Orthopaedic surgeons have considered prophylactic antibiotics to be necessary for patients with joint replacements who undergo any dental procedures, so as to avoid bacteraemia and consequent haematogenous seeding of the implant. We reviewed the scientific literature on the epidemiology, microbiology, pathogenesis and prophylaxis of infections of total hip and knee replacements following dental treatment to ascertain whether this opinion is justified on the basis of the evidence available.

\section{Materials and Methods}

We conducted a PubMed search of the literature to identify English-, French- and Germanlanguage publications before 1 July 2007 using the following terms 'dental', 'joint replacement', 'bacteraemia', 'infection', 'prosthesis', 'arthroplasty', 'dentist' and 'prophylaxis', and paired in a second step with the terms 'recommendations' and 'guidelines'. Bibliographies of relevant articles were hand searched to retrieve further papers. Case reports and references to abstracts of conference presentations were also included. Animal studies and in vitro experiments were excluded.

\section{Results}

Of 144 articles retrieved, 24 were case reports, seven described series involving at least three cases, ${ }^{8} 34$ were review articles, and 48 were retrieved from publications concerning dentistry or maxillofacial surgery, 20 from orthopaedic journals and 11 from literature concerning infectious diseases; 123 were published before 2002 and 21 within the last five years. Of these articles, 23 prospectively investigated the rate of asymptomatic bacteraemia after dental work. No publication concerning the risk of infection was based on randomised or comparative trials. ${ }^{9}$ There were 27 publicaprophylaxis before dental procedures for special circumstances, but $11(7.6 \%)$ did not perceive any benefit. The remaining 106 papers $(73.6 \%)$ took no clear position on the subject. The delay between intra-oral intervention and symptomatic infection ranged between 24 hours ${ }^{10}$ and nine months. ${ }^{11}$ The delay between implantation of the arthroplasty and dental work ranged between $11^{12}$ and 95 months. ${ }^{13}$ tions $(18.8 \%)$ in favour of systemic antibiotic 
Most patients were immunocompetent, and only a few were immunocompromised. ${ }^{13-15}$

\section{Discussion and review of the literature}

Prosthetic joint infections can be classified according to the time of onset as early (less than three months after surgery), delayed (3 to 24 months), or late (more than 24 months after operation). ${ }^{16}$ Most early and delayed infections are presumed to be acquired in the operating theatre, ${ }^{17,18}$ whereas late infections ${ }^{1,16}$ are often attributed to haematogenous seeding. Transient bacteraemia of oral origin may harbour risks for infection of implants, but this occurs rarely as anaerobic bacteria or streptococci of the oral cavity are seldom encountered in infections of arthroplasties where cutaneous Gram-positive organisms such as staphylococci predominate. ${ }^{2,16,19,20}$

A computer simulation model indicated a low incidence of late-stage artificial joint infections associated with dental treatment with 29 to 68 cases per $10^{6}$ dental visits $(0.04 \%),{ }^{21}$ whereas retrospective studies showed an incidence of $0.2 \%$ for total $\mathrm{knee}^{13}$ and $0.1 \%$ for total hip replacements. ${ }^{8}$ Some clinicians have attributed up to $6 \%{ }^{22}$ or $11 \%{ }^{13}$ of all late infections to a dental source.

In most reports, infection developed within two weeks of a dental procedure..$^{9,12,14,15,22-35}$ However, opinion about an oral origin is often an assumption underlined by microbiological results compatible with oral flora because of the lack of a valid alternative explanation. Occasional cases of pre-existing dental or periodontal infections have been described that may have been the source of joint infection rather than a direct dental procedure. ${ }^{12}$ Some papers indicated skin commensals, such as Staphylococcus epidermidis, as causative pathogens, ${ }^{25}$ thereby casting doubt on an oral origin.

Asymptomatic bacteraemia after dental procedures. Dental work that may provoke bacteraemia does not need to be invasive or surgical. It can be caused by periodontal probing, ${ }^{36,37}$ ultrasonic scaling, ${ }^{37-39}$ tooth brushing, ${ }^{37,39}$ orthodontic appliances, ${ }^{40}$ or occur spontaneously due to simple gingivitis. ${ }^{5,41,42}$ Whether chewing, debanding (removal of fixed orthodontic appliances) or gold chain adjustment (fitting a gold orthodontic appliance) may also cause bacteraemia remains a subject of debate. Some reports are affirmative, ${ }^{39,43}$ while others deny such a link. ${ }^{44,45}$ Upper alginate impression or adjustment of arch wires were not found to increase the rates of bacteraemia. ${ }^{46}$

Routine dental operations can produce ten to 240 colonyforming units of pathogens per millilitre of blood. ${ }^{4-49}$ Durack $^{50}$ estimated the incidence of asymptomatic transient bacteraemia to be $60 \%$ after tooth extraction, $88 \%$ after periodontal surgery, $40 \%$ after tooth brushing and $35 \%$ after tonsillectomy. The cumulative risk of 'spontaneous' bacteraemia from periodontitis, oral hygiene and chewing can be considerably higher than from dental interventions. ${ }^{51,52}$ Transient bacteraemia might occur spontaneously up to 12 times each day. ${ }^{53}$ After tooth extraction,
$90 \%$ of positive blood cultures are identified within 30 seconds. ${ }^{42,54-57}$ Most episodes last less than 30 minutes, ${ }^{13,42,49,56,58,59}$ with a mean duration of approximately 11 minutes $^{49}$ and up to 180 minutes at most. ${ }^{60}$ Under normal conditions, the bacteria are rapidly eliminated from the reticuloendothelial system. ${ }^{42}$

The duration of the dental intervention plays a role. In a prospective trial, the incidence of positive blood cultures was significantly higher when the procedure lasted less than three minutes, compared with more than six minutes. ${ }^{61}$ In other studies with orally-induced artificial joint infections, the mean duration of dental procedures was 115 minutes $(75 \text { to } 205)^{13}$ or 65 minutes (45 to 90$) .^{8}$

Microbiology and regimes for prophylaxis. Among 578 patients with infected joint replacements seen at the Mayo Clinic, Rochester, Illinois, 53\% were due to staphylococci, 9\% to streptococci, $6 \%$ to Gram-negative pathogens and $4 \%$ to anaerobes. ${ }^{62}$ In contrast to this variety of bacteria isolated from infected arthroplasties, those found in blood cultures after dental work were streptococci, mostly of the viridans group, $8,12-15,25,36,40,42,46,47,49,52,55-57,61,63$ Gemella, ${ }^{15,37,49,56,57}$ Peptostreptococcus, ${ }^{8,13,32,42,49,56,57}$ Neisseria, ${ }^{42,56}$ Actinomyces, 31,39 , 40,49,56 Prevotella $^{15,22,36,39,42,57,63}$ and other anaerobic bacteria ${ }^{37,39,4}$ $2,47,49,56$ or Gram-negative organisms. ${ }^{13,23,30,37,40,49,56}$ In up to a quarter of the patients the bacteraemia was polymicrobial. ${ }^{13,37,42,61}$

In the 1980 s and early 1990 s penicillins, ${ }^{64}$ cephalosporins $^{21,25,53}$ and erythromycin ${ }^{9,65}$ were advocated as the antibiotics of choice, despite reports of infection by erythromycin-resistant pathogens. ${ }^{14}$ Currently, amoxicillin/ ampicillin ( $2 \mathrm{~g})$, a first- or second-generation cephalosporin, or clindamycin in a dose of $600 \mathrm{mg}$ in cases of intolerance to $\beta$-lactam antibiotics, are considered adequate. 5,6,20,66 The effectiveness of clindamycin has been questioned, ${ }^{55,67}$ partly because of the increasing resistance of streptococci to lincosamide antibiotics. Prophylactic antibiotics are preferably given orally one hour before the dental procedure. ${ }^{5,6,68} \mathrm{~A}$ second dose is seldom recommended. ${ }^{69}$

Analogy to infective endocarditis. Although endocarditis and an infected joint replacement are different clinical entities, ${ }^{5,69,70}$ their management as regards to dental care have similarities. The measures used in endocarditis have been established in experimental data and animal studies. ${ }^{71}$ No randomised trial has ever shown that antibiotic prophylaxis for endocarditis would be effective. ${ }^{50}$ The majority of episodes do not occur after dental procedures. Asymptomatic bacteraemia is much more likely to occur during daily activities than after a dental procedure, and a high percentage of patients develop endocarditis despite correctly administered antibiotic prophylaxis. As a consequence, in April 2007 the recommendations of the American Heart Association were modified in light of the current evidence. ${ }^{72}$ Now, for a procedure that involves the manipulation of gingival tissue, teeth in the periapical region, perforation of the oral mucosa, procedures on the respiratory track or in infected skin and musculoskeletal tissues, antibiotic prophylaxis is restricted to patients with prosthetic cardiac valves, a history of prior 
Table I. Incidence of infections in joint replacements due to haematogenous seeding from dental procedures. Review of the literature (> 100 patients) prior to July 2007

\begin{tabular}{|c|c|c|c|c|c|}
\hline Author & Trial & $\begin{array}{l}\text { Number of } \\
\text { joints }\end{array}$ & $\begin{array}{l}\text { Infections > } 6 \text { mths } \\
(\%)\end{array}$ & $\begin{array}{l}\text { Due to dental procedure in absence of } \\
\text { pre-existing infection }(\%)\end{array}$ & Remarks \\
\hline $\begin{array}{l}\text { Ainscow and } \\
\text { Denham }^{78}\end{array}$ & Prospective & 1112 & - & 0 & $\begin{array}{l}224 \text { patients with den- } \\
\text { tal/surgical therapy }\end{array}$ \\
\hline Jacobson et $\mathrm{al}^{30}$ & Retrospective & 2693 & $30(1.1)$ & $1(0.04)$ & \\
\hline Ching et $\mathrm{al}^{79}$ & Review & 110 & - & 0 & $\begin{array}{l}\text { Four episodes due to } \\
\text { dental infection }\end{array}$ \\
\hline Waldman et $\mathrm{al}^{13}$ & $\begin{array}{l}\text { Retrospective knee } \\
\text { prostheses 1982-93 }\end{array}$ & 3490 & $62(1.8)$ & $7(0.2)$ & $\begin{array}{l}\text { Six of seven patients } \\
\text { with infection due to } \\
\text { dental work had no } \\
\text { prophylaxis }\end{array}$ \\
\hline LaPorte et $\mathrm{al}^{8}$ & $\begin{array}{l}\text { Retrospective hip prostheses } \\
\text { 1982-94 }\end{array}$ & 2973 & $52(1.7)$ & $3(0.1)$ & $\begin{array}{l}\text { No patient with } \\
\text { infection due to dental } \\
\text { work had prophylaxis }\end{array}$ \\
\hline $\begin{array}{l}\text { Jacobsen and } \\
\text { Murray }\end{array}$ & Retrospective & 1855 & $33(1.7)$ & $1(0.05)$ & \\
\hline
\end{tabular}

endocarditis, congenital heart disease, and cardiac transplant recipients who develop valvulopathy. ${ }^{72}$ Some European societies do not yet follow these recommendations ${ }^{73}$ and prefer to revise existing guidelines in cooperation with others. ${ }^{74}$ Human studies with infection as an outcome. In contrast to antibiotic prophylaxis for surgical site infection in general, ${ }^{16,17,75-77}$ few studies have assessed the epidemiology of infections of artificial joints in a large patient database (Table I). Ainscow and Denham ${ }^{78}$ followed 1000 patients with 1112 total joint replacements for a mean of six years. Patients were not advised to take antibiotics during dental procedures. Invasive dental or surgical treatment was carried out on 224 patients. Only three developed infection in their implants, all of which were associated with skin infections. ${ }^{78}$ Jacobson et $\mathrm{al}^{30}$ investigated 2693 joint replacements where only one patient acquired an infection thought to be associated with dental treatment. Ching et al ${ }^{79}$ attributed four episodes of infection in joint replacements from among 110 patients to dental infection, but none to dental manipulation in the absence of pre-existing infection. In another retrospective analysis of 24 late infections in joint replacements, only three were related to dental treatment. Of these, two had a pre-existing dental or periodontal infection. ${ }^{80}$ Waldman et $\mathrm{al}^{13}$ retrospectively analysed 3490 patients with total knee arthroplasties. Late infections were seen in $62(1.8 \%)$, of which only seven $(0.2 \%)$ were possibly related to dental work. Six had not received antibiotic prophylaxis. ${ }^{13}$ Jacobsen and Murray ${ }^{9}$ investigated 1855 hip replacements and, of the 33 infections $(1.7 \%)$ that developed, only one $(0.05 \%)$ could be attributed to dental treatment. LaPorte et $\mathrm{al}^{8}$ retrospectively reviewed the records of 2973 patients with total hip replacements carried out between 1982 and 1994. Late infections were seen in $52(1.7 \%)$, but only three $(0.1 \%)$ were of oral origin and none had received prophylaxis. ${ }^{8}$

Asymptomatic bacteraemia. Brennan et $\mathrm{al}^{41}{ }^{41}$ in a placebocontrolled trial, demonstrated that amoxicillin given before non-surgical dental procedures reduced the incidence of asymptomatic bacteraemia from $20 \%$ in the placebo group to $6 \%$ in those given amoxicillin, indicating that even correct prophylaxis did not guarantee the absence of bacteraemia. Coulter et $\mathrm{al}^{47}$ found a reduction in the incidence of bacteraemia from $63 \%$ to $35 \%$ with antibiotic prophylaxis. Lockhart et $\mathrm{al}^{56}$ noted an incidence of bacteraemia of $89 \%$ following invasive dental care in a placebo group, compared with $33 \%$ in those given amoxicillin $(\mathrm{p}<0.0001)$. Similar observations have been published by others. ${ }^{55,67}$

In a double-blind, randomised placebo-controlled study of 70 adults undergoing single-tooth extraction, the use of a chlorhexidine mouthwash reduced the rate of asymptomatic bacteraemia at one and three minutes after the start of extraction. ${ }^{61}$ Similar findings have been observed using an antibiotic mouthwash ${ }^{81}$ or a povidone-iodine solution. ${ }^{38}$

Existing guidelines, expert opinion and cost-effectiveness analyses. In 1992, the Working Party of the British Society for Antimicrobial Chemotherapy emphasised that there was no evidence to support the use of antibiotic prophylaxis before dental work in patients with joint replacements. ${ }^{82}$ Despite this, $78 \%$ of British orthopaedic surgeons admitted to using antibiotics for prophylaxis before dental procedures. ${ }^{83}$ The Australian Orthopaedic Association Arthroplasty Group emphasised that the risk of a joint replacement becoming infected by a bacteraemia of oral origin is exceedingly low, whereas the risk of an adverse reaction to the antibiotic prophylaxis is higher. ${ }^{84}$ If all patients with joint replacements were to receive antibiotic prophylaxis when having dental treatment, more would die from anaphylactic shock than from infection. This assessment was supported by computer simulation models ${ }^{21}$ that did not confirm the cost-effectiveness of routine prophylaxis. ${ }^{5,6,76}$ Only one group has concluded that antibiotic prophylaxis may be marginally cost-effective for patients with joint replacements. ${ }^{65}$ An analysis from The Netherlands concluded that for some patients with joint disease, but not with joint replacements, antibiotic prophylaxis before dental work was likely to be cost-effective. ${ }^{85}$ 
Table II. Summary of national guidelines/recommendations concerning antibiotic prophylaxis before invasive dental procedures in patients with joint replacements

\begin{tabular}{|c|c|c|c|}
\hline Author & Association & Prophylaxis & Indications \\
\hline \multirow[t]{3}{*}{ Scott et al ${ }^{84}$} & Australian Orthopaedics & Yes & $\begin{array}{l}\text { High-risk dental procedures in immunocompro- } \\
\text { mised patients (immunosuppressive treatment } \\
\text { including systemic steroids, insulin-dependent } \\
\text { diabetes mellitus, rheumatoid arthritis) }\end{array}$ \\
\hline & $\begin{array}{l}\text { American Dental Association; American } \\
\text { Academy of Orthopedic Surgeons }\end{array}$ & Yes & $\begin{array}{l}\text { For the first two years after joint replacement: all } \\
\text { patients for all high-risk dental procedures }\end{array}$ \\
\hline & & & $\begin{array}{l}\text { After } 2 \text { years: previous infection of the artificial joint, } \\
\text { inflammatory arthritis, type-1 diabetes mellitus, } \\
\text { haemophilia, immunosuppression, history of prior or } \\
\text { present malignancy, dental extractions, periodontal } \\
\text { procedures, dental implantation, root canal work, } \\
\text { cleaning if bleeding is anticipated, certain specialised } \\
\text { local anaesthetic injections, placement of orthodontic } \\
\text { bands }\end{array}$ \\
\hline Simmons et $a^{82}$ & $\begin{array}{l}\text { Working Party of British Society for } \\
\text { Antimicrobial Chemotherapy }\end{array}$ & No & $\begin{array}{l}\text { No specific mention of higher-risk groups } \\
\text { Prophylaxis not recommended }\end{array}$ \\
\hline Seymour et al ${ }^{6}$ & $\begin{array}{l}\text { British Orthopaedic Association; } \\
\text { British Dental Association }\end{array}$ & Yes & $\begin{array}{l}\text { Prophylaxis may be considered only in patients with } \\
\text { diabetes mellitus, rheumatoid arthritis, haemophilia, } \\
\text { malignancy, overt oral sepsis, or when dental } \\
\text { treatment is invasive, complex and of long duration } \\
\text { (> } 45 \text { minutes) }\end{array}$ \\
\hline Rossi et al ${ }^{69}$ & Swiss Society for Infectious Diseases & Yes & $\begin{array}{l}\text { Implantation of prosthesis in the last } 12 \text { months } \\
\text { No general recommendation, even for immunocom- } \\
\text { promised patients } \\
\text { Individual decision }\end{array}$ \\
\hline
\end{tabular}

In 1997, the American Dental Association and the American Academy of Orthopedic Surgeons issued an advisory statement ${ }^{5,86}$ which was updated in 2003 , together with the provision of an information leaflet for patients. ${ }^{68}$ They stated that antibiotic prophylaxis is not mandatory for routine dental procedures in most patients with joint replacements, but should be considered in those with an increased risk, including joint replacement within the past two years, previous infection of a joint replacement, inflammatory arthritis, type-1 diabetes mellitus, haemophilia, immunosuppression, a history of previous or current malignancy, dental extractions, periodontal procedures, dental implantation, root canal work, descaling if bleeding was anticipated, specialised injections of local anaesthetic, or placement of orthodontic bands. ${ }^{68}$ Arguments for the inclusion of inflammatory arthritis or immunocompromised patients are based on other trials which demonstrated an increased risk of per-operatively acquired infection, ${ }^{87}$ whereas the other recommendations originate from case reports and/or common sense. ${ }^{5}$ Apart from the two-year limit, the recommendations of the American Dental Association were shared by most authors, ${ }^{13,25,34,52,69,76,88-94}$ but sometimes with many restrictions. ${ }^{6}$ The recommendations of the Swiss Society of Infectious Diseases are very similar, except for the use of prophylaxis during dental procedures within one year of joint replacement and the individuals' decision even for immunocompromised patients. ${ }^{69}$ The rationale behind the recommendations of antibiotic prophylaxis in the early period after joint replacement relies mainly on common sense. Local hyperaemia following surgery and the processes of active healing may make the replacement more vulnerable, but after two years the joint is fully embedded in inactive soft tissue. However, documented clinical evidence for this assumption is lacking. Table II summarises some of the most frequently used guidelines and recommendations.

\section{Conclusions}

Infections of total hip or knee replacements due to haematogenous seeding following dental intervention are very rare. The scientific rationale for systemic or local antimicrobial prophylaxis is very weak at best. ${ }^{70}$ No occurrence of genetically identical strains of Streptococcus in the mouth and joint has been recorded. ${ }^{52}$ According to the criteria of evidence-based medicine, no supportive data in favour of antimicrobial prophylaxis could be found in our review of the literature, and there was no proof that antibiotic prophylaxis could prevent infection. ${ }^{84}$

However, there have been many cases which have suggested that infection of a joint replacement has had an oral origin. ${ }^{11-14}$ Because of the heavy financial, medical and social burden associated with infection of a joint replacement, most authors agree that prevention should be recommended for selected individuals. However, this attitude is based more on fear than on science, and the relationship between the individual orthopaedic surgeon and the patient will greatly influence the decision. To avoid this pitfall, Seymour et $\mathrm{al}^{6}$ proposed leaving the decision to the dental surgeon. However, the dentists and their patients may seek advice from the orthopaedic surgeon or physician in charge.

\section{Recommendations and future perspectives}

Prophylactic antibiotics are not required before a dental intervention in patients with artificial joints and without 
cardiac risk factors. ${ }^{72}$ However, a pre-existing dental infection requires antibiotic treatment and prophylaxis. The guidelines listed in Table II may be helpful. A one-year delay between surgery and the dental procedure should be sufficient. ${ }^{67}$ With a surgical site infection, a single peroperative dose of antibiotic is as effective as prolonged therapy ${ }^{76}$ and a one- to two-hour 'window' before the initial incision has the lowest rate of infection. ${ }^{77}$ We consider that similar timing should be used if it is decided to use prophylactic cover for dental work.

Three important aspects should be borne in mind. First, according to experimental trials, systemic antibiotics could theoretically be replaced by topical antibiotic or oral antiseptic agents. ${ }^{6,38,61,81,95}$ However, further controlled trials, including careful monitoring of adverse events and costeffective evaluation, are needed before any definitive conclusion can be reached. Second, infected foci elsewhere in the body ${ }^{69}$ must be treated first. $5,6,8,13,20,24,33,66,80,84,85,94$ Finally, all patients should be advised to establish and maintain good oral health.

The authors would like to thank R. Sudan for editorial assistance.

No benefits in any form have been received or wil be received from a commercial party related directly or indirectly to the subject of this article.

\section{References}

1. Colonna PC. An arthroplastic operation for congenital dislocation of the hip: a two stage procedure. Surg Gynecol Obstet 1936;63:777-81.

2. Zimmerli W, Trampuz A, Ochsner PE. Prosthetic-joint infections. N Eng/ J Med 2004;351:1645-54.

3. Widmer AF. New developments in diagnosis and treatment of infection in orthopaedic implants. Clin Infect Dis 2001;33:94-106

4. Darouiche RO. Treatment of infections associated with surgical implants. N Eng/ J Med 2004;350:1422-9.

5. American Dental Association, American Academy of Orthopaedic Surgeons. Antibiotic prophylaxis for dental patients with total joint replacements. J Am Dent Assoc 1997; 128:1004-8.

6. Seymour RA, Whitworth JM, Martin M. Antibiotic prophylaxis for patients with joint prostheses: still a dilemma for dental practitioners. Br Dent J 2003;194:649-53.

7. Bengtson S. Prosthetic osteomyelitis with special reference to the knee: risks, treatment and costs. Ann Med 1993;25:523-9.

8. LaPorte DM, Waldman BJ, Mont MA, Hungerford DS. Infections associated with dental procedures in total hip arthroplasty. J Bone Joint Surg [Br] 1999;81-B:56-9.

9. Jacobsen PL, Murray W. Prophylactic coverage of dental patients with artificial joints: a retrospective analysis of thirty-three infections in hip prostheses. Oral Med Oral Pathol 1980;50:130-3.

10. Downes EM. Late infection after total hip replacement. J Bone Joint Surg $[\mathrm{Br}]$ 1977;59-B:42-4.

11. Rubin R, Salvati EA, Lewis R. Infected total hip replacement after dental procedures. Oral Surg Oral Med Oral Pathol 1976;41:18-23.

12. Kaar TK, Bogoch ER, Devlin HR. Acute metastatic infection of a revision total hip arthroplasty with oral bacteria after noninvasive dental treatment. J Arthroplasty 2000;15:675-8.

13. Waldman BJ, Mont MA, Hungerford DS. Total knee arthroplasty infections associated with dental procedures. Clin Orthop 1997;343:164-72.

14. Skiest DJ, Coykendall AL. Prosthetic hip infection related to a dental procedure despite antibiotic prophylaxis. Oral Surg Oral Med Oral Pathol Oral Radiol Endod 1995;79:661-3

15. Akintoye So, Brennan MT, Graber CJ, et al. A retrospective investigation of advanced periodontal disease as a risk factor for septicemia in hematopoietic stem cell and bone marrow transplant recipients. Oral Surg Oral Med Oral Pathol Oral Radiol Endod 2002;94:581-8.

16. Lew DP, Pittet D, Waldvogel FA. Infections that complicate the insertion of prosthetic devices. In: Mayhall CG, ed. Hospital epidemiology and infection control. Third ed. Philadelphia: Lippincott Williams \& Wilkins, 2004:1181-205.
17. Mangram AJ, Horan TC, Pearson ML, Silver LC, Jarvis WR. Guideline for Prevention of Surgical Site Infection: 1999 Centers for Disease Control and Prevention (CDC) Hospital Infection Control Practices Advisory Committee. Am J Infect Control 1999:27:97-132.

18. Little JW. Patients with prosthetic joints: are they at risk when receiving invasive dental procedures? Spec Care Dentist 1997;17:153-60.

19. Baker KA. Antibiotic prophylaxis for selected implants and devices. J Calif Dent Assoc 2000;28:620-6

20. Cutando-Soriano A, Galindo Moreno P. Antibiotic prophylaxis in dental patients with body prostheses. Med Ora/ 2002;7:348-59.

21. Jacobsen JJ, Schweitzer S, DePorter DJ, Lee JJ. Chemoprophylaxis of denta patients with prosthetic joints: a simulation model. J Dent Educ 1988;52:599-604.

22. Steingruber I, Bach CM, Czermak B, Nogler M, Wimmer C. Infection of a total hip arthroplasty with Prevotella loeschii. Clin Orthop 2004;418:222-4.

23. Messini M, Skourti I, Markopulos E, et al. Bacteremia after dental treatment in mentally handicapped people. J Clin Periodonto/ 1999;7:469-73.

24. Bartzokas CA, Johnson $\mathbf{R}$, Jane $\mathbf{M}$, et al. Relation between mouth and haematog enous infection in total joint replacement. BMJ 1994;309:506-8.

25. Thyne GM, Ferguson JW. Antibiotic prophylaxis during dental treatment in patients with prosthetic joints. J Bone Joint Surg [Br] 1991;73-B:191-4.

26. Brand RA. Late hematogenous infection in total joint replacement. J lowa Med Soc 1975;65:388-90

27. Wilson PD Jr, Salvati EA, Blumenfeld EL. The problem of infection in total prosthetic arthroplasty of the hip. Surg Clin North Am 1975;55:1431-7.

28. Stinchfield FE, Bigliani LU, Neu HC, Goss TP, Foster CR. Late hematogenous infection of total joint replacement. J Bone Joint Surg [Am] 1980;62-A:1345-50.

29. Lindqvist C, Slätis P. Dental bacteremia: a neglected cause of arthroplasty infections? Acta Orthop Scand 1985;56:506-8.

30. Jacobson J, Millard HD, Plezia R, Blankenship JR. Dental treatment and late prosthetic joint infections. Oral Surg Oral Med Oral Pathol 1986;61:413-17.

31. Strazzeri JC, Anzel S. Infected total hip arthroplasty due to Actinomyces israelii after dental extraction: a case report. Clin Orthop 1986;210:128-31.

32. Sullivan PM, Johnston RC, Kelley SS. Late infection after total hip replacement caused by an oral organism after dental manipulation: a case report. J Bone Joint Surg [Am] 1990;72-A:121-3.

33. Cruess RL, Bickel WS, von Kessler KL. Infections in total hips secondary to a primary source elsewhere. Clin Orthop 1975;106:99-101.

34. Lattimer GL, Keblish PA, Dickson TB Jr, Vernick CG, Finnegan WJ. Hematogenous infection in total joint replacement: recommendations for prophylactic antibiotics. JAMA 1979;242:2213-14.

35. Cioffi GA, Terezhalmy GT, Taybos GM. Total joint replacement: a consideration for antimicrobial prophylaxis. Oral Surg Oral Med Oral Pathol 1988;66:124-9.

36. Daly CG, Mitchell DH, Highfield JE, Grossberg DE, Stewart D. Bacteremia due to periodontal probing: a clinical and microbiological investigation. J Periodontol 2001;72:210-14

37. Kinane DF, Riggio MP, Walker KF, MacKenzie D, Shearer B. Bacteraemia following periodontol procedures. J Clin Periodonto/ 2005;32:708-13.

38. Cherry M, Daly CG, Mitchell D, Highfield J. Effect of rinsing with povidone-iodine on bacteraemia due to scaling: a randomized-controlled trial. J Clin Periodontol 2007:34:148-55

39. Forner L, Larsen T, Kilian M, Holmstrup P. Incidence of bacteremia after chewing tooth brushing and scaling in individuals with periodontal inflammation. J Clin Periodontol 2006;33:401-7.

40. Burden DJ, Coulter WA, Johnston CD, Mullally B, Stevenson M. The prevalence of bacteraemia on removal of fixed orthodontic appliances. Eur $\mathrm{J}$ Orthod 2004;26:443-7.

41. Brennan MT, Kent ML, Fox PC, Norton HJ, Lockhart PB. The impact of oral disease and nonsurgical treatment on bacteremia in children. J Am Dent Assoc 2007; $138: 80-5$

42. Tomás I, Alvarez M, Limeres J, et al. Prevalence, duration and aetiology of bacteraemia following dental extractions. Oral Dis 2007;13:56-62.

43. Ulualp K, Condon RE. Antibiotic prophylaxis for scheduled operation procedures Infect Dis Clin North Am 1992;6:613-25

44. Murphy AM, Daly CG, Mitchell DH, Stewart D, Curtis BH. Chewing fails to induce oral bacteraemia in patients with periodontal disease. $J$ Clin Periodonto 2006;33:730-6.

45. Lucas VS, Kyriazidou A, Gelbier M, Roberts GJ. Bacteraemia following debanding and gold chain adjustment. Eur J Orthod 2007;29:161-5

46. Lucas VS, Omar J, Vieira A, Roberts GJ. The relationship between odontogenic bacteraemia and orthodontic treatment procedures. Eur J Orthod 2002;24:293-301. 
47. Coulter WA, Coffey A, Saunders ID, Emmerson AM. Bacteremia in children following dental extraction. J Dent Res 1990;69:1691-5.

48. Roberts GJ, Radford $\mathbf{P}$, Holt R. Prophylaxis of dental bacteraemia with oral amoxycillin in children. Br Dent J 1987;162:179-82.

49. Roberts GJ, Jaffray EC, Spratt DA, et al. Duration, prevalence and intensity of bacteraemia after dental extractions in children. Heart 2006;92:1274-7.

50. Durack DT. Prevention of infective endocarditis. N Engl J Med 1995;332:38-44.

51. Pallasch TJ, WahI MJ. Focal infection: new age or ancient history. Endodontic Topics 2003;4:32-45.

52. Trampuz A, Zimmerli W. Antimicrobial agents in orthopaedic surgery: prophylaxis and treatment. Drugs 2006;66:1089-5.

53. Sandhu SS, Lowry JC, Morton ME, Reuben SF. Antibiotic prophylaxis, dental treatment and arthroplasty: time to explode a myth. J Bone Joint Surg [Br] 1997;79B:521-2.

54. Roberts GJ, Gardner P, Simmons NA. Optimum sampling time for detection of dental bacteraemia in children. Int J Cardio/ 1992;35:311-15.

55. Diz Dios P, Tomás Carmona I, Limeros Posse J, et al. Comparative efficacies of amoxicillin, clindamycin, and moxifloxacin in prevention of bacteremia following dental extractions. Antimicrob Agents Chemother 2006;50:2996-3002.

56. Lockhart PB, Brennan MT, Kent ML, Norton HJ, Weinrib DA. Impact of amox icillin prophylaxis on the incidence, nature, and duration of bacteremia in children after intubation and dental procedures. Circulation 2004;109:2878-84.

57. Rajasuo A, Perkki K, Nyfors S, Jousimies-Somer H, Meurman JH. Bacteremia following surgical dental extraction with an emphasis on anaerobic strains. J Dent Res 2004:83:170-4.

58. Robinson L, Kraus FW, Lazansky JP, et al. Bacteremias of dental origin. II: a study of the factors influencing occurrence and detection. Oral Surg Oral Med Oral Pathol 1950;3:923-36

59. Savarrio L, Mackenzie D, Riggio M, Saunders WP, Bagg J. Detection of bacteraemias during non-surgical root canal treatment. J Dent 2005;33:293-303

60. Guntheroth WG. How important are dental procedures as a cause of infective endocarditis? Am J Cardiol 1984;54:797-801

61. Lockhart PB. An analysis of bacteremias during dental extractions: a double-blind placebo: controlled study of chlorhexidine. Arch Intern Med 1996;156:513-20.

62. Steckelberg JM, Osmon DR. Prosthetic joint infections. In: Bisno AL, Waldvogel FA, eds. Infections associated with indwelling medical devices. Third ed. Washington DC: American Society of Microbiology Press, 2000:173-209.

63. Debelian GJ, OIsen I, Tronstad L. Anaerobic bacteremia and fungemia in patients undergoing endodontic therapy: an overview. Ann Periodontol 1998;3:281-7.

64. Jaspers MT, Little JW. Prophylactic antibiotic coverage in patients with total arthroplasty: current practice. J Am Dent Assoc 1985;111:943-8.

65. Tsevat J, Durand-Zaleski I, Pauker SG. Cost-effectiveness of antibiotic prophylaxis for dental procedures in patients with artificial joints. Am J Public Health 1989;79:739-43

66. Curry S, Phillips H. Joint arthroplasty, dental treatment, and antibiotics: a review. J Arthroplasty 2002;17:111-13.

67. Göker K, Güvener $\mathbf{0}$. Antibacterial effects of ofloxacin, clindamycin and sultamicitlin on surgical removal of impacted third molars. J Marmara Univ Dent Fac 1992;1:237-49.

68. American Dental Association, American Academy of Orthopaedic Surgeons. Your joint replacement, dental procedures and antibiotics. J Am Dental Assoc 2003;134:899.

69. Rossi M, Zimmerli W, Furrer H, et al. Antibiotic prophylaxis for late blood-borne infections of joint prostheses. Schweiz Arztezeitung Monatsschr Zahnmed 2005;115:2085-92

70. Wahl MJ. Myths of dental-induced prosthetic joint infections. Clin Infect Dis 1995;29:1420-5

71. Moreillon P. Endocarditis prophylaxis revisited: experimental evidence of efficacy and new Swiss recommendations: Swiss Working Group for Endocarditis Prophylaxis. Schweiz Med Wochenstr 2000;130:1013-26.
72. Wilson W, Taubert KA, Gewitz M, et al. Prevention of infective endocarditis: guidelines from the American Heart Association. Circulation 2007;116:1736-54.

73. Brunner-La Rocca HP, Zuber M, Jaussi A. Endokarditis-Prophylaxe: erste stellungsnahme der SLG zu neuen richtlinien der AHA. Schweizerische Ärzetezeitung 2007:88:1243 (in German).

74. Horstkotte D, Follath F, Gutschik E, et al. Guidelines on prevention, diagnosis and treatment of infective endocarditis exective summary; the task force on infective endocarditis of the European Society of Cardiology. Eur Heart J 2004;25:267-76.

75. Hill C, Flamant R, Mazas F, Evrard J. Prophylactic cefazolin versus placebo in total hip replacement: report of a multicentre double-blind randomised trial. Lancet 1981;1:795-6.

76. Norden CW. Antibiotic prophylaxis in orthopaedic surgery. Rev Infect Dis 1991;13:842-6

77. Classen DC, Evans RS, Pestotnik SL, et al. The timing of prophylactic administration of antibiotics and the risk of surgical-wound infection. $N$ Engl $\mathrm{J}$ Med 1992;326:281-6.

78. Ainscow DA, Denham RA. The risk of haematogenous infection in total joint replacements. J Bone Joint Surg [Br] 1984;66-B:580-2.

79. Ching DW, Gould IM, Rennie JA, Gibson PH. Prevention of late haematogenous infection in major prosthetic joints. J Antimicrob Chemother 1989;23:676-80.

80. Maderazo EG, Judson S, Pasternak H. Late infections of total joint prostheses: a review and recommendations for prevention. Clin Orthop 1988;229:131-42.

81. Vergis EN, Demas PN, Vaccarello SJ, Yu VL. Topical antibiotic prophylaxis for bacteremia after dental extractions. Oral Surg Oral Med Oral Pathol Oral Radiol Endod 2001;91:162-5.

82. Simmons NA, Ball AP, Cawson RA, et al. Case against antibiotic prophylaxis for dental treatment of patients with joint prostheses. Lancet 1992;339:301.

83. Sandhu SS, Lowry JC, Reuben SF, Morton ME. Who decides on the need for antibiotic prophylaxis in patients with major arthroplasties requiring dental treatment: is it a joint responsibility? Ann $R$ Coll Surg Eng/ 1997;79:143-7.

84. Scott JF, Morgan D, Avent M, Graves S, Goss AN. Patients with artificial joints: do they need antibiotic cover for dental treatment? Aust Dent J 2005;50:45-53.

85. Krijnen P, Kaandorp CJ, Steyerberg EW, et al. Antibiotic prophylaxis for haematogenous bacterial arthritis in patients with joint disease: a cost effectiveness analysis. Ann Rheum Dis 2001;60:359-66.

86. Barry JM, Ferguson CD. Current dental concepts in antibiotic prophylaxis for total joint replacement patients. Gen Dent 2000;48:170-2.

87. Wilson MG, Kelley K, Thornhill TS. Infection as a complication of total knee replacement arthroplasty: risk factors and treatment in sixty-seven cases. J Bone Joint Surg [Am] 1990;72-A:878-83.

88. Yagiela JA. Prophylactic antibiotics: cardiac and prosthetic considerations. J Calif Dent Assoc 1995:23:29-40.

89. Marculescu CE, Osmon DR. Antibiotic prophylaxis in orthopedic prosthetic surgery. Infect Dis Clin North Am 2005;19:931-46.

90. Rose RE. Routine prophylactic antibiotics for arthroplasty patients receiving dental care: is is necessary? West Indian Med J 2003:52:317-20.

91. Deacon JM, Pagliaro AJ, Zelicof SB, Horowitz HW. Prophylactic use of antibiotics for procedures after total joint replacement. J Bone Joint Surg [Am] 1996;78A:1755-70.

92. Curran JB, Ogle RG, Waite DE. Infection of abnormal heart valves and total joint prosthesis following dental procedures. Northwest Dent 1976;55:192-6.

93. Field EA, Martin MV. Prophylactic antibiotics for patients with artificial joints undergoing oral and dental surgery: necessary or not? Br J Oral Maxillofac Surg 1991;29:341-6.

94. McGowan DA, Hendrey ML. Is antibiotic prophylaxis required for dental patients with joint replacements? Br Dent J 1985;158:336-8.

95. Tzukert A, Leviner E, Sela M. Prevention of infective endocarditis: not by antibiotics alone: a 7-year follow-up of 90 dental patients. Oral Surg Oral Med Oral Pathol 1986;62:385-8. 